\title{
Creating women's capabilities through microcredit in Bangladesh
}

\author{
Mohammad Mojammel Hussain Raihan and Mohammad Jasim Uddin \\ Department of Sociology, Shahjalal University of Science \& Technology, Sylhet, Bangladesh.
}

\begin{abstract}
Group-based microcredit, an extension of small amounts of collateral-free institutional loans to poor with limited access to formal credit markets, has become one of the most popular development strategies in Bangladesh. The underlying logic behind the group lending model is that the provision of small loans for poor women, in particular, could facilitate socio-economic development and livelihood improvement in the rural areas. Microcredit to women is considered as a tool for empowering women with increased self-esteem, decisionmaking capability and new income-earning opportunities. However, the impact of microcredit on marginalized people remains debated. While the positive impact of microcredit on millions of poor people's lives has been documented by various studies, there are also studies that challenge the arguments about women empowerment through microcredit involvement. Based on interviews with 175 of economically and socially vulnerable female microcredit borrowers, the present study contributes to the continuing debate over how or if microcredit intervention enhances women's capabilities in achieving health care utilization, food and nutrition security, and personal freedom at the local level in Bangladesh. Indices were developed to quantify the capabilities of women. To measure different aspects of capabilities, variables were analyzed through univariate and bi-variate analyses. The results of the present study confirm that microcredit involvement improves women's basic capabilities but it is not as significant as attested by earlier studies.
\end{abstract}

Keywords: Micro-credit, borrower women, capabilities, personal freedom, family income.

\section{INTRODUCTION}

In Bangladesh, women are socially and economically less fortunate than men. Almost in every sector of society, there are inequities between men and women. The life of rural women in Bangladesh, by and large, is dominated by a patriarchal system which upholds a rigid division of labor that restricts women's mobility, roles and responsibility. Women at the local level, to a large extent, suffer from being economically and socially invisible. Economic invisibility stems from their subordinate position within the rural division of labor, with their primary role in the home and much of their work being unpaid or underpaid. Women's participation in wage and salaried-employment is also extremely skewed towards lower paid jobs. Social invisibility comes from the perceptions that women are weaker, illiterate and objects of welfare. The social norms inhibit women to interact with people beyond their family quarters and kinship groups networks. Moreover, social norms restrict women's movement in the market transaction and constrain their potential to generate incomes, limiting their economic dependence on men or other male members of the family (Westergaard, 1983; Bruece, 1989; Abecassis, 1990; Uddin, 2015).

In 1980s, microcredit to women has become an important strategy for alleviating poverty at the local level in Bangladesh. Microfinance organizations provide

${ }^{*}$ Corresponding author (mjauddin@yahoo.com)

This article is published under the Creative Commons CC-BY-ND License (http://creativecommons.org/licenses/ by-nd/4.0/).This license permits use, distribution and reproduction, commercial and non-commercial, provided that the original work is properly cited and is not changed anyway. 
small amounts of credit to poor people through their microcredit programmes. In addition, they provide savings and insurance services. The panorama of poverty, powerlessness and gendered inequalities in the rural areas formed the context of microcredit intervention. The Grameen Bank (GB) of Bangladesh first started grouplending microcredit program as a pilot project in Jobra- a village near the Chittagong University Campus- in 1976 lead by a Bangladeshi Professor Dr. Mohammed Yunus. Following the success of GB's group-lending model, now thousands of governmental and non-governmental organizations across rural Bangladesh are providing small-scale loans to the marginalized people, particularly poor women (Shams, 1992; Begum \& Chakraborty, 1995). It is generally assumed that women involvement in microcredit program would bring direct benefits to women themselves. More specifically, microcredit to women is considered as a tool for empowering women with increased self-esteem, decision-making capability and new income-earning opportunities.

Poverty and malnutrition both have a womanfaced facet. It is often argued that, in most developing countries 60 to 80 percent of food is produced by women, though most of the world's poor are women (FAO, 2011). Diets of populations all over the world are generally ascertained by the accessibility of local food and food practices. Dietary patterns evolved to maintain good health, primarily with satisfaction of hunger. Bangladesh has made substantial progress in food production and economic growth. The 1990s was indicated by a good progress in food production, particularly rice, together with other food items like wheat, potato, vegetables, fish, meat and milk (Halder \& Urey, 2003). In spite of food system improvements and economic growth, food distribution inequity still affects the poor very disproportionately. In Bangladesh, like many other developing countries, poverty, social norms and values play strong adverse roles on food intake by girls and mothers: "they need most but eat last and least" (ibid., 2003). Poor women and girls are more likely to suffer from malnutrition, especially pregnant women and adolescent girls. Sometimes customs in rural Bangladesh, such as mothers and wives having to take food after the other family members are fed, prevent them from getting enough food during meals (Titumir \& Rahman, 2011). Poor women also often sacrifice their own food for children and men (Sheema et al., 2016). As a result, they mostly suffer from the serious consequences of nutritional defficiency (Sheema et al., 2016; Dowler, 2001). However, there is also increasing evidence that rural poor women have experienced rapid change in their situation over the past decade owing to different socio-economic development interventions, particularly microcredit to women (Hashemi et al.,
1996; Mizan, 1994). Meyer (2002) observes that microfinance contributes to poverty alleviation and food security through supplying loans, providing other financial services that enhance investment, and creating employment opportunities for the participant.

In view of the aim of this present study, the research question sets to investigate whether microcredit intervention improves women's basic capabilities in achieving health care utilization, food and nutrition security, and personal freedom at the local level in Bangladesh.

\section{EXISTING STUDIES}

A plethora of scholarly studies on microcredit claimed that microcredit increased women's income-earning capacities which reduced their as well as household's poverty. Women's income-earning capacities accordingly affect social relations and enable women to overcome gender-related constraints within the households and get exposure to the outside community. Osmani (1998), for example, reveals that microcredit extended to poor women improves their income earning capacity and increases their ability to enjoy greater power in a broader sense in the household. Credit enables women to earn cash income for the family which has an immediate effect on raising their self-esteem as well as their esteem in the eyes of others. Thus, credit to women has an empowering effect on women. In addition, through the process of participation in microcredit programs, women have come out of the quarters of their households and have paved their way to mingle with people beyond the neighborhood community. This exposure of women to the outside of family boundaries and the formation of networks with other women beyond their family quarters and kinship groups/networks have led them to develop self-confidence and courage they need so as to exert power to both within and beyond their households. Similarly, Hashemi et al. (1996), in their study on Grameen Bank and Bangladesh Rural Advancement Committee (BRAC), presented the positive impact of credit on the empowerment of women. They found that credit program has a significant effect on all the empowerment dimensions which they set in their research except for two: relative freedom from the domination by the family and political/legal awareness on the composite empowerment score. Some studies suggest that microcredit has the decisive role in increasing female borrower's income-earning ability, leading to stronger decision making power and ability to overcome gender-related constraints (Hashemi et al., 1996; Khandker, 1998; Khandker \& Pitt, 1998). Research evidences also suggest that microcredit not only increases the earning ability but also increasingly 
promotes the basic capabilities of women (Graflund, 2013; Hashemi et al., 1996; Holvoet, 2005). However, there is no real consensus among scholars on the impact of microcredit on women's empowerment. Some studies showed that male members of the households often take control over the credit thus, leading women to a more vulnerable position within the household (Ackerly, 1995; Goetz, 2001; Goetz \& Sen Gupta, 1996; Rahman, 1999).

In his ethnographic study on GB microcredit, Rahman (1999) explored that its "public transcript" of poverty alleviation and women's empowerment are at odds with a "hidden transcript", which is patriarchal and involves the hegemonic exploitation of poor women by men and even by wealthier women. Rahman clearly explicates that women are subjected to violence and aggression when they cannot repay their loans. In some cases, the empowerment of women causes violent relationships with their husbands due to lack of their certain freedoms or capabilities (Rahman, 1999; Pyles, 2008).

Uddin (2015) considers micro-finance as the product of neo-liberalism and capitalist technology which northern international agencies and neo-liberal state bodies have actively promulgated over the past few decades to alleviate poverty and empower women at the local level in Bangladesh. The researcher argues that credit granted to women is not entirely a noble mission in Bangladesh. According to him, there is,

"a glaring ideological clash between the microfinance industry's articulation of a public transcript that supposedly encourages women to become independent economic agents whereas it actually relies upon their subordinate position in society and their being embedded in patriarchal gender relations to ensure its own survival" (Uddin, 2015: p. xiii).

Considering all the different arguments, this study endeavored to examine if microcredit program improves women's basic capabilities in achieving health care utilization, food and nutrition security, and personal freedom at the local level in Bangladesh. It is argued that people can enjoy all the freedom to control their own lives and can escape all types of vulnerabilities only when they have certain basic capabilities (Sen, 2001; Nussbaum, 2000). Drawing on the theoretical ideas of Sen (2001) and Nussbaum (2000), the present study attempted to investigate whether microcredit brings changes in the very basic areas of women's capabilities such as (a) health care utilization, (b) food intake and nutrition, and (d) personal freedom at the local level in Bangladesh.

\section{CAPABILITY APPROACH}

To adopt a conceptual framework, the present study followed the capability approach of Amartya Sen and Nussbaum, who focused on people's capabilities when making normative calculations and eventually criticized the evaluations depending completely on utilities or income, commodities and measurable resources (Robyens, 2002: p. 3). In Sen's capability approach, capability and functioning are reciprocally dependent, that is, one affects the other and vice versa. "Functioning" can be denoted by what a person is really able to do or be; while "capabilities" indicate what a person can do or be; that is the range of choices that are open to an individual (Lister, 2004: p. 16). Every person has freedom (capability) to value his/her life in their own way and they have the right to lead the type of life they want. If someone has the capabilities and opportunities, they can choose the various options that exist in front of them. In other words, one's capability allows him/ her to function in his/her own way (Cagatay, 1998: p. 7). Functioning can be taken as an achievement, whereas a capability indicates the ability to achieve something. Therefore, functioning is linked with living conditions which include different aspects of living. By contrast, capabilities are related with notions of freedom and choice, e. g. the real opportunities by which people shape their current living. Therefore, capabilities are defined as the substantive freedoms that persons enjoy to lead such kind of life in which it is supposed to have a reason to value or the freedom to lead one type of life over another or the ability to achieve functioning (Sen, 2001: p. 87; 1992: p. 40).

Sen (1984) recognized that capabilities depend crucially on a number of circumstances, both personal and social, which may include personal heterogeneities, environmental diversities, variations in social climate, differences in relational perspectives and distribution within the family etc. Besides these, he presumed that providing necessary facilities; e.g. work in the formal sector, fundamental rights to the citizens etc., is the responsibility of the government and society. Nussbaum (2000: pp. 33-34) broaden Sen's capabilities dimension incorporating 10 central human capabilities and utilized the approach within the philosophical framework of feminism where she argues that a universal approach is important to fight against injustices of women. Her list of capabilities includes: (i) Life; (ii) Bodily Health; (iii) Bodily Integrity; (iv) Senses, Imagination and Thought; (v) Emotions; (vi) Practical Reason; (vii) Affiliation; (viii) Other Species; (ix) Play and (x) Control over one's Environment. However, Sen (1984) often attempted to clarify instances of intrinsically valuable capabilities, such as being able to live long, 
escape avoidable morbidity, be well nourished, be able to read, write and communicate, take part in literary and scientific pursuits etc. He said freedom in one area may influence freedom in other areas as well (Sen, 1993: p. 47; 1985). As a result, the researchers assume that if microcredit to women enables them to work outside household it is also conducive to enhancing their freedom from hunger, illness and relative deprivation.

From the above discussion, it is clear that capability means the actual living that people are able to achieve or have the freedom to achieve, which is different from functioning, i. e. actual achievement in a given social context. Therefore, it can be argued that poor people have low functioning not just because of their low income or low monetary levels but because they experience a lack of freedom or ability to achieve certain functioning. Without distinctive capabilities (e. g. freedom) people can never choose to do anything in their own way; they cannot be empowered or self-determine their lives. To formulate the indicators of capability, this study accumulates the list of capabilities provided by Sen and Nussbaum and seeks to know the impacts of microcredit on borrower women's basic capabilities. According to Sen (2001), basic capabilities can be regarded as;

"the substantive freedoms include elementary capabilities like being able to avoid such deprivation as starvation, under-nourishment, escapable morbidity and premature mortality, as well as the freedoms that are associated with being literate and numerate, enjoying political participation and uncensored speech and so on" (Sen, 2001: p. 36).

\section{Indicators of capabilities}

This indicators considered in the study are as follows:

1. Women's ability to Health Care Utilization (HCU): (i) Ability to seek treatment or make an appointment with the doctor for personal sickness; (ii) Ability to buy medicine, and (iii) Ability to bear diagnostic charges.

2. Women's ability to intake Healthy Food and Nutrition (HFN): (i) Ability to Intake Protein e.g. fish or meat; (ii) Ability to buy fruit, and (iii) Ability to buy milk \& egg.

3. Women's Personal Freedom (PF): (i) Ability to spend household's money for family purpose without permission of husband; (ii) Ability to share opinion with husband about having children or adoption of family planning, and (iii) Ability to comfortably go to the local market and neighboring vilage for shopping or selling.

Here, HCU (ability to "Health Care Utilization") is consistent with the capabilities of life and bodily health; HFN (ability to intake "Healthy Food and Nutrition") is related to the component of ability to be well nourished; and lastly PF ("Personal Freedom") represents the human capability of bodily integrity, ability to participate in community life, mobility and sense, imagination and thought.

\section{METHODS AND DATA}

The empirical data for this study was collected from the female microcredit borrowers of Grameen Bank of Tuker Bazar \& Khandirgaw Union in Sylhet, Bangladesh. All the married women (younger than 50 years), who took credit for more than one year or more were considered as the population of the study. It is assumed that women who involve with microcredit for several years may gain more capabilities than those who are not. There were 420 borrower women who took credit during the study period in 2015. Among them, a total of 320 women fell into the above criteria. So the population of this study was 320 . The sample size 175 was determined by applying the Cochran's method and random table was used to select the specific sample unit (Cochran, 1977).

The structured interview strategy was applied to collect primary data to address the research objectives. Oral consent was taken from each participant just before carrying out the interview. They were interviewed only after getting their consent. Likert scale was used for quantification of the basic capabilities of women. In this regard, the assigned value for the responses are: Fully incapable $=1$; Incapable $=2 ;$ Undecided $=3 ;$ Capable $=4$ and Fully capable $=5$.

To measure different aspects of capabilities, variables were analyzed through uni-variate and bi-variate analysis. The authors constructed a basic capability index considering all the indicators and sub-indicators discussed in the previous section of this paper, with a view to determine the level of women's capabilities. This index has been developed in two stages. In the first stage, Basic Capability Index (BCI) of women for a single indicator consisting of different sub-indicators is calculated and secondly, Overall Basic Capability Index (OBCI) for women consisting of different indicators is created. Besides, the hypotheses were tested to know the strength of the relationship between years of microcredit involvement and basic capability variables. 
Table 1: Socio-demographic profile

\begin{tabular}{lrr}
\hline & Frequency $(\mathrm{n}=175)$ & Percentage \\
\hline Years of involvement & & \\
1- 2 years & 30 & 17.14 \\
3-4 years & 96 & 54.86 \\
5-6 years & 49 & 28.00 \\
Mean: 3.22, SD: 0.31 & & \\
Credit is controlled by & & \\
Wife & & \\
Husband & 52 & 29.71 \\
& & 70.29 \\
Age structure (years) & 123 & \\
$18-22$ & & \\
$23-27$ & & 17 \\
$28-32$ & 31 & 17.71 \\
$33-37$ & 43 & 24.57 \\
$38-42$ & 34 & 19.43 \\
$43-47$ & 23 & 13.14 \\
\hline
\end{tabular}

Mean: 35.13, SD: 7.22

Members of household

3-4

5-6

7-8

9-10

11-12

Mean: 7, SD: 1.411

Number of children

$1-2$

3-4

5-6

$57 \quad 32.57$

Mean: 4, SD: 0.56

Occupation of the respondents

Housewife

Domestic worker

Khata Sewing

BetherKaj

Ayah

Tailoring

1.14

Hotel Work

Husband's occupation

Fish seller

Vegetable seller

Rickshaw puller

2.29

CNG driver

14.29

Shopkeeper

5.71

Fruit seller 
- continued from page 115

\begin{tabular}{lrr} 
Service & 8 & 4.57 \\
Carpenter & 12 & 6.86 \\
Cart Puller & 5 & 2.86 \\
& & \\
Monthly family & & \\
income (Taka) & & \\
$5,000-10,000$ & 63 & 36 \\
$10,000-15,000$ & 87 & 49.71 \\
$15,000-20,000$ & 25 & 14.29 \\
Mean: 12130 & & \\
\hline
\end{tabular}

Table 2: Health Care Utilization

\begin{tabular}{|c|c|c|c|c|c|c|c|c|c|c|c|c|}
\hline \multirow[t]{3}{*}{ Capability } & \multicolumn{4}{|c|}{$\begin{array}{r}\text { Could seek own treatment or } \\
\text { make appointment with } \\
\text { doctor } \\
(\mathrm{n}=175)\end{array}$} & \multicolumn{4}{|c|}{$\begin{array}{l}\text { Ability to buy medicine for } \\
\qquad \text { own }(\mathrm{n}=175)\end{array}$} & \multicolumn{4}{|c|}{$\begin{array}{l}\text { Ability to bear diagnostic } \\
\text { charges for own disease } \\
(n=175)\end{array}$} \\
\hline & & Before & & After & & Before & & After & & Before & & After \\
\hline & $f$ & $\%$ & $\mathrm{f}$ & $\%$ & $\mathrm{f}$ & $\%$ & $f$ & $\%$ & f & $\%$ & $f$ & $\%$ \\
\hline $\begin{array}{l}\text { Fully } \\
\text { incapable }\end{array}$ & 13 & 7.43 & 3 & 1.7 & 22 & 12.57 & 4 & 2.3 & 28 & 16 & 21 & 12 \\
\hline Incapable & 82 & 46.86 & 49 & 28.0 & 45 & 25.71 & 28 & 16.0 & 97 & 55.43 & 85 & 48.57 \\
\hline Undecided & 38 & 21.71 & 25 & 14.29 & 62 & 35.43 & 46 & 26.29 & 36 & 20.57 & 21 & 12 \\
\hline Capable & 35 & 20 & 74 & 42.29 & 44 & 25.15 & 77 & 44 & 11 & 6.29 & 36 & 20.57 \\
\hline $\begin{array}{l}\text { Fully } \\
\text { capable }\end{array}$ & 7 & 4.0 & 24 & 13.71 & 2 & 1.14 & 20 & 11.43 & 3 & 1.71 & 12 & 6.86 \\
\hline
\end{tabular}

\section{RESULTS AND DISCUSSION}

\section{Socio-demographic profile}

Sylhet Sadar Upazila is $323.17 \mathrm{sq} \mathrm{km}$, located in between $24^{\circ} 52^{\prime}$ and $25^{\circ} 02^{\prime}$ north latitudes and in between $91^{\circ} 01^{\prime}$ 'and $91^{\circ} 40^{\prime}$ ' east longitudes. Besides, there are eight unions where the literacy rates in the studied areas were 40.14 percent and 49.19 percent, respectively. The main sources of income are agriculture and non-agriculture laborers, transport workers, construction laborers, religious service, rent and remittance etc. (Bangladesh Bureau of Statistics, 2001). Table 1 provides selected characteristics of the studied respondents. The study findings show that 54.83 percent of the respondents have been involved with GB for 3 to 4 years and about 28 percent of the respondents have been engaged with more than 5 to 6 years. It is also showed that the mean years of involvement was more than 3 years where the standard deviation is 0.31 .

The study reveals that husbands and the male household members are the main users of credit. It is also seen that about 42.28 percent of the respondents belonged to ages 23 to 32 years, whereas 19.43 percent of the respondents belonged to the age group 33-37 years. Besides, the mean age of the respondents is about 35 years old and the standard deviation is 7.22. Data shows that most of the families, on an average, are composed of five to eight members. Nearly half of the respondents (46.86 percent) have three to four children, followed by about one-third of the respondents (32.57 percent) having five to six children.

Work status of a woman reflects her position in the family as well as her status in the society. Based on their responses, it was found that more than half (56.57 percent) of the borrowers are housewives. The other significant occupations include khata sewing and betherkaj, domestic worker, ayah, tailoring and chef in hotel. With respect to their husband's occupations, the study reveals that around 40.57 percent were engaged in fishing business, followed by vegetable seller (18.86 percent), CNG driver (14.29 percent), carpenter (6.86 percent), shopkeeper (5.71 percent), fruit seller (4 percent), services (4.57 percent) and cart puller (2.86 percent). Classification of the respondents by family income divulges that about half (49.71 percent) of the respondents' monthly family income was 10,000 - 
15,000 Taka, whereas just over one-third of the total respondent's monthly family income belonged within the range of 5,000-10,000 Taka.

\section{Basic capabilities of the women}

Researchers have used different methods and metrics to assess the impact of microcredit on household income, employment generation and women empowerment. The present study is based on the borrower's recall of the before-after situation. As mentioned before, the capability is a broader concept that includes multiple components. In this study, capabilities of the respondents were calculated based on three basic areas: the ability to health care utilization, ability to intake healthy food and nutrition, and ability to enjoy personal freedom. Again each indicator was operationalized by three subindicators.

\section{Health Care Utilization}

Health care utilization is essential to enjoy bodily and mentally good health, where good health is one of the important basic capability indicators (Pyles, 2008: p. 31). In assessing the impact of microcredit on health care utilization of women, they were asked about their ability to seek treatment or make an appointment with the doctor for personal sickness, ability to buy medicine and bear diagnostic charges. It is revealed (Table 2) that microcredit involvement has some impact on women's capability in achieving better health care services. It is seen that before joining the microcredit program, about 54 percent of the respondents claimed themselves as incapable of receiving health care services but the percentage had decreased by $29.7 \%$ as a result of microcredit involvement. Research also suggested that before microcredit involvement, about 25.71 percent were incapable of buying medicine and 55.43 percent were incapable of bearing diagnostic charges but after microcredit involvement, the percentages reduced by 16 and 48.57 , respectively.

\section{Intake Healthy Food \& Nutrition}

Balanced diet and protein are important substances for the growth of human body as well as to enjoy a healthy life (Whitney \& Rolfes, 2007). There are many important sources of protein: e.g. fish, meat, fruit and egg, milk etc. (Whitney \& Rolfes, 2007). With regard to the intake of food and nutrition, the respondents were asked whether their ability to buy fish/meat, fruits and egg/milk has been changed due to microcredit involvement. The study findings show (Table 3 ) that after getting involved with microcredit the majority of the respondent's capabilities to intake fish/meat have been changed positively. They could now buy fish, meat, fruit, milk and egg, which were unaffordable before microcredit investment.

\section{Personal Freedom}

Freedom is one of the key capabilities, which determines women's economic and social position and empowerment. According to capability approach, people should have the freedom to choose and self-determine their lives. More specifically, personal freedom can be considered as an important component which leads to bodily integrity as well as judged by its own rights (Pyles, 2008). In this study, personal freedom is used as an essential capability indicator and operationalized by the following variables: ability to spend household's money for family purpose without permission of husband, ability to share opinion with husband about having children or adoption of family planning, and ability to comfortably go to the local market and neighboring village for shopping or selling.

Table 3: Healthy Food intake \& Nutrition

\begin{tabular}{|c|c|c|c|c|c|c|c|c|c|c|c|c|}
\hline \multirow[t]{3}{*}{ Capability } & \multicolumn{5}{|c|}{$\begin{array}{l}\text { Ability to intake protein e.g. fish/meat } \\
\qquad(\mathrm{n}=175)\end{array}$} & \multicolumn{3}{|c|}{$\begin{array}{l}\text { Ability to buy fruit } \\
\qquad(\mathrm{n}=175)\end{array}$} & \multicolumn{4}{|c|}{$\begin{array}{l}\text { Ability to buy milk \& egg } \\
\qquad(\mathrm{n}=175)\end{array}$} \\
\hline & \multicolumn{3}{|c|}{ Before } & \multicolumn{2}{|l|}{ After } & Before & \multicolumn{2}{|r|}{ After } & \multicolumn{2}{|r|}{ Before } & \multicolumn{2}{|c|}{ After } \\
\hline & f & $\%$ & $\mathrm{f}$ & $\%$ & $f$ & $\%$ & $\mathrm{f}$ & $\%$ & $\mathrm{f}$ & $\%$ & $\mathrm{f}$ & $\%$ \\
\hline $\begin{array}{l}\text { Fully } \\
\text { incapable }\end{array}$ & - & - & - & - & 37 & 21.14 & 18 & 10.29 & - & - & - & - \\
\hline Incapable & 42 & 24 & 25 & 14.29 & 92 & 52.57 & 49 & 28 & 82 & 46.86 & 70 & 40 \\
\hline Undecided & 105 & 60 & 85 & 48.57 & 31 & 17.71 & 23 & 13.14 & 73 & 41.71 & 28 & 16 \\
\hline Capable & 21 & 12 & 47 & 26.86 & 7 & 4.0 & 58 & 33.14 & 13 & 7.43 & 56 & 32 \\
\hline $\begin{array}{l}\text { Fully } \\
\text { capable }\end{array}$ & 7 & 4 & 18 & 10.29 & 8 & 4.57 & 27 & 15.43 & 7 & 4 & 21 & 12 \\
\hline
\end{tabular}


Table 4: Personal freedom

\begin{tabular}{|c|c|c|c|c|c|c|c|c|c|c|c|c|}
\hline \multirow[t]{3}{*}{ Capability } & \multicolumn{4}{|c|}{$\begin{array}{r}\text { Could spend household's } \\
\text { money for family without } \\
\text { permission }(\mathrm{n}=175)\end{array}$} & \multicolumn{4}{|c|}{$\begin{array}{l}\text { Could share opinion with husband } \\
\text { for having children or family planning } \\
\qquad(\mathrm{n}=175)\end{array}$} & & \multicolumn{3}{|c|}{$\begin{array}{r}\text { Comfortably go to the local } \\
\text { market or neighboring } \\
\text { village for selling or } \\
\text { shopping }(\mathrm{n}=175)\end{array}$} \\
\hline & & efore & & After & & efore & & After & & Before & & After \\
\hline & f & $\%$ & $\mathrm{f}$ & $\%$ & $\mathrm{f}$ & $\%$ & $\mathrm{f} \%$ & & $\mathrm{f}$ & $\%$ & $\mathrm{f}$ & $\%$ \\
\hline $\begin{array}{l}\text { Fully } \\
\text { incapable }\end{array}$ & 14 & 8.0 & 9 & 5.14 & 12 & 6.9 & 5 & 2.86 & 42 & 24 & 22 & 12.57 \\
\hline Incapable & 25 & 14.3 & 13 & 7.43 & 92 & 52.6 & 38 & 21.71 & 86 & 49.14 & 31 & 17.71 \\
\hline Undecided & 97 & 55.4 & 37 & 21.14 & 40 & 22.9 & 25 & 14.3 & 22 & 12.57 & 12 & 6.86 \\
\hline Capable & 30 & 17.1 & 82 & 46.86 & 23 & 13.1 & 85 & 48.57 & 17 & 9.71 & 83 & 47.43 \\
\hline Fully capable & 9 & 5.1 & 34 & 19.43 & 8 & 4.6 & 22 & 12.57 & 8 & 4.57 & 27 & 15.43 \\
\hline
\end{tabular}

With regard to control over household's money, the data of the present study reveals that microcredit involvement has brought change in the situation of the female borrowers (see also, Uddin, 2015). Besides, microcredit to women brings some positive changes in the areas of ability to involve in the family decision and ability to move comfortably. With reference to involve in the decision, data shows that microcredit borrowers are now more capable than during their previous situation. Microfinance is assumed to positively increase women's mobility beyond their family quarters and kinship groups. The women's involvement in the microfinance funded new businesses and expansions in the existing ones are expected to open opportunities for them to gain new experience, which in turn would enable them to contribute with something constructive to the benefits of their families or the communities (Tseng, 2011). The result in Table 4 shows that women's mobility beyond their living quarters has increased due to microcredit involvement. More categorically, it can be concluded that after getting involved with microcredit organization women's personal freedom has increased significantly.

\section{Basic Capability Index (BCI)}

To develop Basic Capability Index from the Likert scale, Participation Level Index (PLI) was used (Roy et al., 2007: p. 56). Following the adoption of the PLI, indices were constructed to determine comparative measures of all basic capabilities elements: e.g. Health Care Utilization; Healthy Food Intake and Nutrition, and Personal Freedom. Therefore,

Basic Capability Index (BCI) of individual activities $=$

$$
\frac{f_{1} x_{1}+f_{2} x_{2}+f_{3} x_{3}}{M}
$$

Where, $f_{i}=$ frequency of $i^{\text {th }}$ category of responses

$\mathrm{x}_{\mathrm{i}}=$ assigned value for $\mathrm{i}^{\text {th }}$ category of responses

$\mathrm{M}=$ maximum score

$=$ maximum possible participation score

$$
=5 \sum_{\mathrm{i}=1}^{5} \mathrm{f}_{\mathrm{i}}
$$

The PLI value actually measures the proportion of cumulative current participation of members in any given activity in terms of maximum possible participation of all members (Roy et al., 2007: p. 56). In this study, the BCI value represents the basic capabilities of the respondents in terms of their capability to do certain functions. Functioning, in a sense, is one kind of participation by the respective members. Hence, PLI is used to quantify the capability level of the respondents in this study. The value ranged from 0 to 1 . The higher the BCI value, the higher the level of capability in any given indicators of capabilities. Therefore, the index values of different elements of capabilities are given in Table 5 and Table 6.

From the index value of every indicator, it is shown that respondent's basic capability is increased after involvement with micro-credit program. For example, the index value of the ability to health care services before involvement with credit program was 0.533; however, after involvement, the value is 0.677 . Besides, in the case of buying fruit, the index values before and after involvement are 0.437 and 0.631 , respectively. Furthermore, for the indicator of ability to control over resources (household's money), before involvement the index value was 0.594 , whereas after involvement the value is 0.736 . 
Table 5: Capability Index of different factors

\begin{tabular}{lcr}
\hline Capability sub-indicators & $\begin{array}{r}\text { Before involvement } \\
\text { (Index Value) }\end{array}$ & $\begin{array}{r}\text { After involvement } \\
\text { (Index Value) }\end{array}$ \\
\hline $\begin{array}{l}\text { Health Care Utilization } \\
\text { Ability to seek treatment or make } \\
\text { appointment with doctor }\end{array}$ & 0.533 & 0.677 \\
$\begin{array}{l}\text { Ability to buy Medicine } \\
\text { Ability to bear diagnostic charges } \\
\text { for own disease }\end{array}$ & 0.553 & 0.692 \\
$\begin{array}{l}\text { Food Intake \& Nutrition } \\
\text { Ability to intake protein e.g. fish } \\
\text { or meat }\end{array}$ & 0.445 & 0.523 \\
$\begin{array}{l}\text { Ability to buy fruit for own } \\
\text { Ability to buy milk \& egg for own }\end{array}$ & 0.592 & 0.666 \\
$\begin{array}{l}\text { Personal Freedom } \\
\text { Ability to control over household's } \\
\text { money }\end{array}$ & 0.437 & 0.631 \\
$\begin{array}{l}\text { Ability to share opinion in family decision } \\
\text { Ability to go to local market or } \\
\text { neighborhood }\end{array}$ & 0.537 & 0.632 \\
\hline
\end{tabular}

Table 6: Capability Index of the main indicators

\begin{tabular}{lrr}
\hline Capability indicators & $\begin{array}{r}\text { Before involvement } \\
\text { (Index value) }\end{array}$ & $\begin{array}{r}\text { After involvement } \\
\text { (Index value) }\end{array}$ \\
\hline Health Care Utilization & 0.510 & 0.631 \\
Food \& Nutrition Requirements & 0.522 & 0.643 \\
Personal Freedom & 0.516 & 0.715 \\
\hline
\end{tabular}

\section{Overall Basic Capability Index (OBCI)}

From the individual indicators of basic capabilities, one can calculate the overall basic capabilities possessed by the respondents. Hence, the overall Basic Capability Index (OBCI) can be expressed as:

$$
(O B C I)=\frac{\mathrm{BCI}_{1}+\mathrm{BCI}_{2}+\cdots+\mathrm{BCI}_{\mathrm{N}}}{\mathrm{N}}
$$

Where, $\mathrm{N}=$ total number of indicators of basic capabilities (in this case 3 ).

The value of $\mathrm{OBCI}$ lies between 0 and 1 . The higher the level of OBCI, the higher is the level of basic capabilities and vice versa. From the analysis, it is shown that the index values before and after involvement are 0.516 and 0.663 , respectively. It can be concluded that after getting involved with microcredit, respondents' overall capability has increased from moderate level to significant level.

\section{Testing the hypothesis of zero correlation}

\section{Hypothesis-1}

$\mathrm{H}_{\mathrm{o}}$ : There is no relationship between years of involvement with microcredit (YI) and ability to use health care utilization.

$\mathrm{H}_{\mathrm{A}}$ : Years of involvement with microcredit and ability to receive health care utilization are related.

\section{Hypothesis-2}

$\mathrm{H}_{\mathrm{o}}$ : There is no relationship between years of involvement with microcredit (YI) and ability to buy fish/meat.

$\mathrm{H}_{\mathrm{A}}$ : Years of involvement with microcredit and ability to buy fish/meat are related.

\section{Hypothesis-3}

$\mathrm{H}_{\mathrm{o}}$ : There is no relationship between years of involvement with microcredit (YI) and ability to buy medicine. 
$\mathrm{H}_{\mathrm{A}}$ : Years of involvement with microcredit and ability to buy medicine are related.

Here the value of correlation coefficient $r$ is used as an estimate of the population correlation coefficient $p$ and a statistical test was performed to see if there is any correlation between the variables. In this hypothesis test, the null hypothesis typically asserts that there is no correlation:

$\mathrm{H}_{\mathrm{o}}: p=0$; while the alternatives hypothesis states that

$\mathrm{H}_{\mathrm{A}}: \mathrm{p} \neq 0$; Therefore, a two-tailed test can be performed and the test statistic is,

$$
t=\frac{r \sqrt{(n-2)}}{\sqrt{\left(1-r^{2}\right)}} ;(\text { Islam, 2011) }
$$

This is distributed as $\mathrm{t}$ with $\mathrm{n}-2$ degrees of freedom. Therefore, the degrees of freedom in the hypothesis test are 173 (175-2). In Table 7, the decisions of hypotheses are represented according to their calculated and tabulated value.

From the hypothesis test, it is found that in every case the tabulated value was lower than that of the calculated value. Based on the value, the null hypotheses were rejected and at the same time, alternative hypotheses were accepted.

\section{CONCLUDING REMARKS}

Microcredit has been a major interest of development scholars for decades, given their effectiveness as an engine of upward mobility among the poor at the local level. The present study has contributed to the understanding of the social impact of microcredit on the possibility of women to gain abilities in the basic realms of their lives. This study reveals the role of microcredit in fostering women's capabilities, particularly, their ability to health care utilization, ability to intake healthy food and nutrition and ability to enjoy personal freedom. The study reveals that microcredit has a positive effect on female borrower's health care utilization, food intake, and nutrition capabilities. This study also resonates with other studies which articulate the fact that in most of the cases the husband uses credit money for his purposes and therefore, the borrower women are unable to exercise control over credit (Rahman, 1999; Uddin, 2015). Years of microcredit involvement was expected to have a positive impact on female borrowers' control over resources. The findings of the study, however, suggest that this does not have to be the case. From the association, it is confirmed that the years of involvement and food intake capability are positively related and that female borrower's capability to control over household's money has increased comparatively. This result is consistent with some other studies as well (e.g. Goetz \& Gupta, 1996; Rahman, 1999; Uddin, 2015). In this study, it was found that microcredit is becoming increasingly important in rural societies of Bangladesh. In brief, the present study confirms that microcredit involvement improves women's basic capabilities but it was not as significant as attested by earlier studies. Microcredit to some extent acts to foster economic empowerment of the household, which in turn increases women's basic capabilities at the local level in Bangladesh.

Table 7: Hypothesis test values

\begin{tabular}{lrr}
\hline Hypotheses & Calculated value & Tabulated value $(173$ degrees of freedom) \\
\hline $\begin{array}{l}\text { Hypothesis-1 } \\
(\mathrm{r}=0.412)\end{array}$ & 5.948 & $2.576\left(^{*}\right)$ Rejected \\
$\begin{array}{l}\text { Hypothesis-2 } \\
(\mathrm{r}=0.312)\end{array}$ & 4.320 & $2.576\left(^{*}\right)$ Rejected \\
$\begin{array}{l}\text { Hypothesis-3 } \\
(\mathrm{r}=0.188)\end{array}$ & 2.528 & $1.960\left(^{* *}\right)$ Rejected \\
\hline
\end{tabular}

$\left(^{*}\right)$ level of significance $(0.01)$; and $\left.{ }^{* *}\right)$ level of significance $(0.05)$ 


\section{REFERENCES}

Abecassis, D. (1990) Identity, Islam and Human Development in Rural Bangladesh, Dhaka, Bangladesh: University Press.

Ackerly, B. A. (1995) Testing the tools of development: Credit Programs, loan involvement, and women's empowerment, IDS Bulletin, 26(3) [Online] Available from: https://core.ac.uk/ download/pdf/43540266.pdf [Accessed: $5^{\text {th }}$ January 2015] pp: 56-68.

Bangladesh Bureau of Statistics (2001) Bangladesh Population Census, Dhaka: Government of Bangladesh.

Begum, A. and Chakraborty, K. (1995) Economic Contribution of Rural Women and their Participation in the Household Decision Making Process in Bangladesh, The Bangladesh Journal of Agricultural Economics, XVIII(1) [Online] Available from: https://ageconsearch.umn.edu/bitstream/202648/2/ Resear_02\%20Vol-XVIII_1.pdf [Accessed: $5^{\text {th }}$ January 2015] pp: 51-69.

Bruece, J. (1989) Homes Divided, World Development, 17(7), pp: 91-97.

DOI: https://doi.org/10.1016/0305-750X(89)90162-9

Cagatay, N. (1998) Gender and Poverty, Social development and Poverty Elimination Branch, Working Paper, New York: UNDP [Online] Available from: http://www.pnud.org/content/ dam/aplaws/publication/en/publications/poverty-reduction/ poverty-website/gender-and-poverty/GenderandPoverty.pdf [Accessed: $5^{\text {th }}$ January 2015] pp: 1-23.

Cochran, W. G. (1977) Sampling Techniques, $3^{\text {rd }}$ Ed., New Jersey: John Wiley \& Sons [Online] Available from: https://archive. org/details/Cochran1977SamplingTechniques_201703/page/ n43 [Accessed: $7^{\text {th }}$ May 2015].

Dowler, E. (2001) Inequalities in diet and physical activity in Europe, Public Health \& Nutrition, 4(2B) [Online] Available from: https:/www.cambridge.org/core/journals/public-healthnutrition/article/inequalities-in-diet-and-physical-activity-ineurope/21F41F447D9F7F01040EFFAD66A399BE [Accessed: $5^{\text {th }}$ January 2015] pp: 701-709.

DOI: https://doi.org/10.1079/PHN2001160

FAO (2011) The role of women in agriculture [Online] Available from: http://www.fao.org/docrep/013/am307e/am307e00.pdf [Accessed: $2^{\text {nd }}$ April 2014]

Goetz, A. M. and Sen Gupta, R. (1996) Who takes the Credit? Gender, Power, and Control over Loan Use in Rural Credit Programme in Bangladesh, World Development, 24(1) [Online] Available from: https://www.sciencedirect.com/science/article/ abs/pii/0305750X9500124U [Accessed: $4^{\text {th }}$ February 2015] pp: 45-63.

DOI: https://doi.org/10.1016/0305-750X(95)00124-U
Goetz, A. M. (2001) Women Development Workers: Implementing Rural Credit Programmes in Bangladesh, New Delhi: Sage Publications, London: Thousand Oaks.

Graflund, F. (2013) The Impact of Microcredit on Women's Empowerment - A Case Study of Microcredit in The Tangail District, Bangladesh, Department of Economics at the University of Lund 2013:5, Minor Field Study Series, 225 [Online] Available from: https://iveatlund.lu.se/intranets/ LUSEM/NEK/mfs/MFS/225.pdf [Accessed: $3^{\text {rd }}$ February 2015] pp: 1-65.

Halder, S. and Urey I. (2003) Changing Food Consumption Patterns: Implications for Nutrition and Livelihoods, Research and Evaluation Division, BRAC, Bangladesh.

Hashemi, S. M., Schuler, S. R. and Riley, A. P. (1996) Rural Credit Programs and Women's Empowerment in Bangladesh, World Development, 24(4) [Online] Available from: https://www.sciencedirect.com/science/article/abs/ pii/0305750X9500159A [Accessed: $7^{\text {th }}$ January 2015] pp: 635653.

DOI: https://doi.org/10.1016/0305-750X(95)00159-A

Holvoet, N. (2005) The Impact of Microfinance on Decision Making Agency: Evidence from South India, Development and Change, 36(1) [Online] Available from: http:// www.spandanaindia.com/pdfs/Microfinance $\% 20$ on $\% 20$ Decision\%20making\%20Agency.pdf.pdf [Accessed: $5^{\text {th }}$ January 2015] pp: 75-102.

Islam, M. N. (2011) An Introduction to Research Methods, $2^{\text {nd }}$ ed. Kamrul Hasan Mullick, Dhaka. Kaplan, G. A. and Keil, J. (1993) Socioeconomic Factors and Cardiovascular Disease: A Review, Circulation 88 (1973-1998).

Khandker, S. and Pitt, M. (1998) The Impact of Group-Based Credit Programs on Poor Households in Bangladesh: Does the Gender of Participants Matter?, Journal of Political Economy, 106(5) [Online] Available from: http://www1.worldbank.org/ prem/poverty/ie/dime_papers/411.pdf [Accessed: $5^{\text {th }}$ April 2015] pp: 958-996.

Khandker, S. R. (1998) Fighting poverty with Micro-credit: Experiences in Bangladesh, New York, NY: Oxford University Press, The World Bank.

Lister, R. (2004) Poverty, Cambridge: Polity Press.

Meyer, Richard L. (2002) Microfinance, Poverty Alleviation and Improving Food security: Implications for India, In Lal, Rattan., Hansen, David O. and Uphoff, Norman. (2002) Food Security and Environmental Quality in the Developing World, Florida, USA: CRC Press.

Mizan, A. N. (1994) In Quest of Empowerment: The Grameen Bank Impact on Women's Power and Status, Dhaka, Bangladesh: University Press Limited. 
Nussbaum, M. C. (2000) Women and Human Development: The Capabilities Approach, Cambridge: Cambridge University Press [Online] Available from: https:/genderbudgeting. files.wordpress.com/2012/12/nussbaum_women_ capabilityapproach2000.pdf [Accessed: $1^{\text {st }}$ January 2015] pp: $1-336$.

DOI: https://doi.org/10.1017/CBO9780511841286

Osmani, L. N. (1998) The Grameen Bank Experiment: Empowerment of Women through Microcredit, Women and Empowerment: Illustration from the Third World, London, UK: Macmillan.

Pyles, L. (2008) The capabilities approach and violence against women: Implication for social development, International Social Work, 51 [Online] Available from: https://journals. sagepub.com/doi/10.1177/0020872807083912 [Accessed: $1^{\text {st }}$ June 2015] pp: 25-36.

DOI: https://doi.org/10.1177/0020872807083912

Rahman, A. (1999) Micro-credit Initiatives for Equitable and Sustainable Development: Who Pays?, World Development, 27(1) [Online] Available from: https://www.sciencedirect.com/ science/article/abs/pii/S0305750X98001053 [Accessed: $2^{\text {nd }}$ March 2015] pp: 67-82.

DOI: https://doi.org/10.1016/S0305-750X(98)00105-3

Robyenes, I. (2002) Sen's capability approach and gender inequality, Conference on promoting women capabilities, Von Hugel Institute, St. Edmunds College Cambridge [Online] Available from: https://pdfs.semanticscholar. org/b4f9/139c13371f8e553e390bd1211cd583224043.pdf [Accessed: $3^{\text {rd }}$ February 2015] pp: 1-31.

Roy, M. K., Bhattacharjee, M. K. and Chowdhury, N. A. (2007) Community Participation in Forest Resource Management: A Micro-Level Analysis, Journal of Bangladesh Economic Association, 1, pp: 53-66.

Sen, A. K. (1985) Commodities and Capabilities, Oxford: Elsevier Science Publishers.

Sen, A. K. (1984) Resources, Values and Development, Oxford: Basil Blackwell.

Sen, A. K. (2001) Development as Freedom, New Delhi: Oxford University Press.
Sen, Amartya K. (1992) Inequality Re-examined, Oxford: Clarendon Press.

Sen, A. (1993) Capability and Well-Being, In Nussbaum, M. and Sen, A., The Quality of Life, Oxford: Oxford University Press [Online] Available from: http://www.oxfordscholarship.com/ view/10.1093/0198287976.001.0001/acprof-9780198287971 [Accessed: $5^{\text {th }}$ June 2015] pp: 30-52.

DOI: https://doi.org/10.1093/0198287976.001.0001

Shams, M. K. (1992) Designing Effective Credit Delivery System for the Poor: The Grameen Bank Experience, Dhaka: Grameen Bank.

Sheema, M. K., Rahman, M. R., Yasmin, Z., Chowdhury, M. S. R., Ali, M. Y., Rabbi, M. F. and Jabed, A. (2016) Food Habit and Nutritional Status of Rural Women in Bangladesh, American Journal of Rural Development, 4(5) [Online] Available from: http://pubs.sciepub.com/ajrd/4/5/3/index.html [Accessed : $3^{\text {rd }}$ July 2015] pp: 114-119.

Titumir, R. A. M. and Rahman, K. M. M. (2011) Achieving the MDGs Targets in Nutrition: Does Inequality Matter? Unnayan Onneshan: The Innovators Policy Brief [Online] Available from: http://www.unnayan.org/reports/Policy\%20Brief $\% 20$ on $\% 20$ Achieving $\% 20$ the $\% 20$ MDGs $\% 20$ Targets $\% 20$ in $\% 20$ Nutrition-\%20Does\%20Inequality\%20Matter.pdf [Accessed: $3^{\text {rd }}$ July 2015] pp: 4-21.

Tseng, C. C. (2011) Microfinance and Amartya Sen's Capability Approach, Thesis Paper, University of Birmingham Research Archive [Online] Available from: http:/etheses.bham. ac.uk/2921/1/Tseng11PhD.pdf [Accessed: $12^{\text {th }}$ June 2015] pp: $1-321$.

Uddin, M. J. (2015) The Micro-politics of Microcredit: Gender and Neoliberal Development in Bangladesh, London \& NY: Routledge.

DOI: https://doi.org/10.4324/9781315691688

Westergard, K. (1993) Pauperization and Rural Women in Bangladesh: A case study, Dhaka: BARD.

Whitney, E. and Rolfes, S. R. (2007) Understanding Nutrition, Belmont, USA: Wadsworth Publishing. 